\title{
PERBANDINGAN KEMAMPUAN KOMUNIKASI MATEMATIS SISWA YANG BELAJAR DENGAN MODEL PEMBELAJARAN KOOPERATIF TIPE THINK TALK WRITE DAN TIPE THINK PAIR SHARE DI SMP NEGERI 3 PERCUT SEI TUAN
}

\author{
Nuraini $^{1}$, Edy Surya ${ }^{2}$ \\ ${ }^{1}$ Mahasiswa S1 Prodi Pendidikan Matematika, FMIPA, Universitas Negeri Medan, Medan \\ ${ }^{2}$ Dosen Prodi Pendidikan Matematika, FMIPA, Universitas Negeri Medan, Medan \\ E-mail : ainiritonga0501@gmail.com
}

\begin{abstract}
This study aims to determine whether the mathematical communication skills of students who learn by using cooperative learning model Think Talk Write type is higher than the mathematical communication ability of students who learn by using cooperative learning model Think Pair Share type. This type of research is a quasi experiment. The population of this research is all students of class VII of SMP Negeri 3 Percut Sei Tuan. Research sampling was done by cluster sampling and many samples in this research consist of 2 classes, first class is called experimental class I and second class is called experiment class II. The instrument used in this research is a test of mathematical communication ability consisting of 4 items of description. From result of data processing obtained on result of posttest mean score of mathematical communication ability of student 13,4722 for experiment class I and 12,0556 for experiment class II. Based on hypothesis testing that is done by using t test with obtained. This shows that being out of acceptance then based on the test obtained that rejected so it can be stated that the mathematical communication skills of students who learn by using cooperative learning model Think Talk Write type higher than the mathematical communication skills of students who learn by using cooperative learning model type Think Pair Share at SMP Negeri 3 Percut Sei Tuan.
\end{abstract}

Keywords: Mathematical Communication, Think Talk Write, Think Pair Share

\section{PENDAHULUAN}

Matematika memiliki peran sebagai bahasa simbolik yang memungkinkan terwujudnya komunikasi secara cermat dan tepat. Matematika tidak hanya sekedar alat bantu berfikir tetapi matematika sebagai wahana komunikasi antar siswa dan guru dengan siswa. Semua orang diharapkan dapat menggunakan bahasa matematika untuk mengkomunikasikan informasi maupun ide-ide yang diperolehnya. Banyak persoalan yang disampaikan dengan bahasa matematika, misalnya dengan menyajikan persoalan atau masalah ke dalam model matematika yang dapat berupa diagram, persamaan matematika, grafik dan tabel.

Setiap siswa harus belajar matematika dengan alasan bahwa matematika merupakan alat komunikasi yang sangat kuat, sistematis dan tepat karena matematika sangat erat dengan kehidupan kita. Dengan berkomunikasi siswa dapat meningkatkan kosa kata, mengembangkan kemampuan berbicara, menulis ide-ide secara sistematis, dan memiliki kemampuan belajar yang lebih baik. Tinungki (2015) dalam penelitiannya menyatakan :

"Pentingnya pembelajaran matematika tidak terlepas dari perannya dalam segala aspek kehidupan. Mengkomunikasikan ide-

Nuraini, Edy Surya. Perbandingan Kemampuan Komunikasi Matematis Siswa Yang Belajar Dengan Model Pembelajaran Kooperatif Tipe Think Talk Write dan Tipe Think Pair Share di SMP Negeri 3 Percut Sei Tuan. Jurnal Inspiratif, Vol 3, No. 3 Desember 2017. 
ide dengan menggunakan bahasa matematika bahkan lebih praktis, sistematis, dan efisien. Untuk mengatasi kesulitan siswa yang memiliki pemahaman yang cukup tentang materi matematika, komunikasi yang baik harus dibangun dalam proses pembelajaran."

Sejalan dengan pendapat di atas, belajar matematika diharapkan dapat membantu siswa mengkomunikasikan gagasan serta menjadikan siswa lebih mudah untuk memahami matematika dengan adanya komunikasi dalam pembelajaran. Seperti yang dinyatakan NCTM (dalam Ansari, 2016:14) bahwa matematika sebagai alat komunikasi (mathematics as communication) merupakan pengembangan bahasa dan simbol untuk mengkomunikasikan ide matematik, sehingga siswa dapat:

"(1) mengungkapkan dan menjelaskan pemikiran mereka tentang ide matematik dan hubungannya, (2) merumuskan defenisi matematik dan membuat generalisasi yang diperoleh melalui investigasi (penemuan), (3) mengungkapkan ide matematik secara lisan dan tulisan, (4) membaca wacana matematika dengan pemahaman, (5) menjelaskan dan mengajukan serta memperluas pertanyaan terhadap matematika yang telah dipelajarinya, dan (6) menghargai keindahan dan kekuatan notasi matematik, serta peranannya dalam mengembangkan ide/gagasan matematik."

Tetapi kenyataannya banyak siswa yang mengalami kesulitan dalam bermatematika. Siswa selalu mengalami kesulitan dalam mengkomunikasikan persoalan matematika ke dalam bahasa matematika Bahkan siswa yang cerdas dalam matematika sering kurang mampu menyampaikan pemikirannya. Seolah-olah mereka tidak mau berbagi ilmu dengan yang lainnya. Jika hal ini terus dibiarkan maka siswa akan semakin kurang mampu berkomunikasi menggunakan matematika (Ramellan dkk, 2012).

Di sisi lain sebagian besar siswa beranggapan bahwa pelajaran matematika merupakan pelajaran yang sangat sulit dan rumit, sehingga siswa malas untuk mempelajarinya. Sikap siswa tersebut disebabkan oleh pengalaman siswa sebelumnya. Pengalaman siswa tersebut di antaranya persepsi siswa terhadap pelajaran matematika maupun guru matematiknya. Mereka beranggapan bahwa matematika adalah pelajaran yang sulit, bahkan guru yang mengajar pelit jika memberikan nilai, pemarah, selera humor rendah. Adanya persepsi siswa yang negatif baik terhadap pelajarannya maupun gurunya membawa dampak pada prestasi belajar matematika siswa (Syaifuddin, 2013).

Selain itu juga, banyak siswa yang merasa bosan, sama sekali tidak tertarik dan bahkan benci terhadap matematika. Ini juga dapat menjadi pemicu rendahnya komunikasi matematis siswa. Hal ini bisa disebabkan karena matematika hanya diajarkan sebagai kumpulan angka-angka, rumus-rumus, atau langkah-langkah yang harus dihafalkan dan siap pakai untuk menyelesaikan soal. Hal tersebut berdasarkan pembelajaran matematika yang cenderung menekankan aspek hafalan dan sangat kurang pada perkembangan nilai. Pembelajaran matematika cenderung pada pencapaian target kurikulum dan buku pegangan, bukan pada pemahaman bahan yang dipelajari (Syaifuddin, 2013).

Oleh karena itu, kemampuan komunikasi dalam pembelajaran matematika sangat diperlukan. Seperti yang dinyatakan oleh Mardiyah (2014), kesulitan belajar matematika pada siswa berhubungan dengan kemampuan belajar yang kurang sempurna. Kekurangan tersebut dapat terungkap dari penyelesaian persoalan matematika yang tidak tuntas. Ketidaktuntasan tersebut dapat diduga karena kesalahan penggunaan konsep dan prinsip dalam penyelesaian soal matematika yang diperlukan. Konsep dan prinsip matematika dapat pula ditinjau dari segi kemampuan komunikasi matematika siswa.

Keterampilan berkomunikasi merupakan kemampuan siswa untuk mengekspresikan ide-ide mereka, menjelaskan, dan mendiskusikan konsepkonsep matematika secara koheren dan jelas. Ini adalah kemampuan siswa untuk

Nuraini, Edy Surya. Perbandingan Kemampuan Komunikasi Matematis Siswa Yang Belajar Dengan Model Pembelajaran Kooperatif Tipe Think Talk Write dan Tipe Think Pair Share di SMP Negeri 3 Percut Sei Tuan. Jurnal Inspiratif, Vol 3, No. 3 Desember 2017. 
menjelaskan dan membenarkan tindakan dalam prosedur dan proses baik secara lisan maupun tulisan. Seperti yang ditunjukkan Stever bahwa semua efek dalam belajar dapat ditingkatkan melalui interaksi dan komunikasi. Tantangan siswa untuk berkomunikasi baik secara lisan maupun tulisan di kelas matematika dapat membantu memperdalam pemahaman konseptual mereka. Ketika siswa didorong untuk berinteraksi dengan orang lain, mereka mampu membangun pemahaman individu dan pembentukan konsep (Lomibao et al, 2016).

Menurut Baroody (dalam Umar, 2012) sedikitnya ada 2 alasan penting yang menjadikan komunikasi dalam pembelajaran matematika perlu menjadi fokus perhatian yaitu :

"(1) mathematics as language; matematika tidak hanya sekedar alat bantu berpikir ( $a$ tool to aid thinking), alat untuk menemukan pola, atau menyelesaikan masalah namun matematika juga "an invaluable tool for communicating a variety of ideas clearly, precisely, and succinctly" dan (2) mathematics learning as social activity; sebagai aktivitas sosial, dalam pembelajaran matematika, interaksi antar siswa, seperti juga komunikasi guru-siswa merupakan bagian penting untuk "nurturing children's mathematical potential."

Hal di atas menegaskan bahwa, kemampuan komunikasi matematis siswa sangat perlu untuk dikembangkan, karena melalui komunikasi matematis siswa dapat melakukan organisasi berpikir matematisnya baik secara lisan maupun tulisan, siswa bisa memberi respon dengan tepat, baik di antara siswa itu sendiri maupun antara siswa dengan guru selama proses pembelajaran berlangsung. Suhaedi (2012) menyatakan siswa yang memiliki kemampuan komunikasi matematis yang baik, cenderung dapat membuat berbagai representasi yang beragam, sehingga lebih memudahkan siswa dalam mendapatkan alternatif-alternatif penyelesaian berbagai permasalahan matematis.

Kenyataan di lapangan menunjukkan bahwa hasil pembelajaran matematika di
Indonesia dalam aspek komunikasi matematis masih rendah. Rendahnya kemampuan komunikasi matematis ditunjukkan dalam studi Rohaeti (2003) bahwa rata-rata kemampuan komunikasi matematis siswa berada dalam kualifikasi kurang. Demikian juga Purniati (2003) menyebutkan bahwa respons siswa terhadap soal-soal komunikasi matematis umumnya kurang. Hal ini dikarenakan soalsoal pemecahan masalah dan komunikasi matematis siswa masih merupakan hal-hal yang baru, sehingga siswa mengalami kesulitan dalam menyelesaikannya (Fachrurazi, 2011).

Untuk melihat apa penyebab rendahnya kemampuan komunikasi matematik siswa, maka salah satu yang perlu dicermati adalah proses pelaksanaan pembelajaran. karena pada saat proses pembelajaranlah materi pelajaran dapat dipahami oleh siswa. Sukendar (2014) menyatakan :

"Rendahnya kemampuan siswa tidak terlepas dari peran guru dalam mengelola pembelajaran. Pada proses pembelajaran guru cenderung memindahkan pengetahuan yang dimiliki ke pikiran siswa, mementingkan hasil daripada proses, mengajarkan secara urut halaman per halaman tanpa membahas keterkaitan antar konsep atau masalah. Dalam kondisi seperti ini, akhirnya tidak jarang guru hanya memberikan catatan pelajaran kemudian menjelaskannya. Pembelajaran menjadi berpusat pada guru, sementara siswa jadi pasif karena hanya mendengarkan dan mencatat pelajaran yang diberikan oleh guru. Aktivitas pembelajaran seperti ini mengakibatkan terjadinya penghafalan konsep dan prosedur, sehingga aktivitas penalaran dan komunikasi siswa rendah karena tidak distimulus oleh guru. Guru sering memberikan soal kepada siswa yang berasal dari buku paket untuk dikerjakan di rumah, soal tersebut tidak menstimulus komunikasi dan penalaran siswa. Siswa tidak dirangsang oleh guru untuk melakukan proses berfikir."

Hal ini juga didukung oleh Nartani, dkk (2015) bahwa kenyataan di lapangan

Nuraini, Edy Surya. Perbandingan Kemampuan Komunikasi Matematis Siswa Yang Belajar Dengan Model Pembelajaran Kooperatif Tipe Think Talk Write dan Tipe Think Pair Share di SMP Negeri 3 Percut Sei Tuan. Jurnal Inspiratif, Vol 3, No. 3 Desember 2017. 
juga menunjukkan bahwa keterbatasan pengetahuan guru dan kebiasaan belajar siswa di kelas dilakukan dengan cara konvensional dan hal ini tidak dapat meningkatkan kemampuan komunikasi matematika siswa secara optimal. Lain halnya, jika bahan ajar matematika yang disajikan dengan abstrak oleh guru dan guru tidak melibatkan siswa dalam belajar.

Syaifuddin (2013) juga menyatakan, pada kenyataannya banyak dijumpai guru dalam mengajar matematika masih menggunakan cara konvensional (tradisional). Dalam pembelajaran matematika dengan cara konvensional kegiatan belajar mengajar banyak didominasi oleh guru, sehingga yang aktif adalah guru. Dengan demikian peserta didik cenderung pasif, hanya mendengarkan, memperhatikan, dan mencatat apa yang telah diterangkan oleh guru. Hal ini menyebabkan peserta didik cenderung malas berfikir untuk mengerjakan tugas yang diberikan oleh guru dan tidak sedikit peserta didik yang merasa jenuh dalam mengikuti pelajaran matematika. Surya (2013) menemukan pada penelitian bahwa faktor guru, antara lain : a) masih ada guru yang pendidikannya tidak sesuai dengan mata pelajaran, b) penguasaan guru terhadap materi matematika yang diajarkan masih sangat rendah. Hal ini dapat dilihat dari hasil probing tes guru yang menunjukkan masih terdapat guru yang hanya menguasai $40 \%$ dari tes probing yang dilakukan, c) Guru kurang menguasai materi pembelajaran secata menyeluruh. Hal ini berdasarkan masukan dari angket siswa yang menyatakan bahwa siswa sulit memahami pelajaran yang diberikan guru. Guru seharusnya melibatkan siswa secara aktif dalam belajar tidak hanya ceramah. Guru sebaiknya menggunakan fasilitas dan sumber belajar yang lebih baik lagi dan guru sebaiknya memperbaiki cara mengajar, d) Model pembelajaran yang digunakan guru matematika masih belum bervariasi umumnya guru mengajar dengan metode ceramah. Kemampuan pedagogik guru juga masih minim, kegiatan pembelajaran yang dilakukan masih konvensional, siswa hanya pasif sebagai pendengar. Pembelajaran umumnya satu arah dimana guru memberikan atau menyalin materi atau rumus-rumus, memberikan contoh soal matematika dan dilanjutkan dengan tugas di kelas atau di rumah..Pembelajaran tidak sepenuhnya mengacu pada RPP yang ada, menurut guru ini terjadi karena keterbatasan alat

Oleh sebab itu, Rahmalia dkk (2012) mengungkapkan, perlu dilakukan inovasi pembelajaran yang dirancang agar siswa terbiasa mengkonstruksi pengetahuannya dan dapat menumbuh kembangkan kemampuan komunikasi matematis. Di antaranya, memfasilitasi bermacam keterampilan komunikasi matematis, seperti membaca, menjelaskan, mendengar dan menalar, yang didukung oleh rasa tanggung jawab dan keberanian serta optimis pada diri siswa. Namun, apapun metode, pendekatan, model pembelajaran yang digunakan diharapkan penekanannya lebih pada siswa untuk mengkonstruksi sendiri pengetahuannya dan guru lebih berperan sebagai fasilitator bukan sebagai sumber informasi utama.

Untuk mewujudkan itu banyak cara dan metode yang dapat digunakan, salah satunya adalah penggunaan model pembelajaran kooperatif. Menurut Isjoni (2011:12) Cooperative Learning atau pembelajaran kooperatif merupakan strategi belajar dengan sejumlah siswa sebagai anggota kelompok kecil yang tingkat kemampuannya berbeda. Hal ini bermanfaat untuk melatih siswa menerima perbedaan dan bekerja dengan teman yang berbeda latar belakangnya. Dengan model kooperatif dapat diterapkan untuk memotivasi siswa berani mengemukakan pendapatnya, menghargai pendapat teman dan saling memberikan pendapat. Oleh sebab itu, cooperative learning sangat baik untuk dilaksanakan karena siswa dapat bekerja sama dan saling tolong-menolong mengatasi tugas yang dihadapinya. Model pembelajaran kooperatif yang dapat diterapkan yaitu model pembelajaran kooperatif tipe Think Talk Write dan model

Nuraini, Edy Surya. Perbandingan Kemampuan Komunikasi Matematis Siswa Yang Belajar Dengan Model Pembelajaran Kooperatif Tipe Think Talk Write dan Tipe Think Pair Share di SMP Negeri 3 Percut Sei Tuan. Jurnal Inspiratif, Vol 3, No. 3 Desember 2017. 
pembelajaran kooperatif tipe Think Pair Share. Surya (2009) menyatakan pembelajaran kooperatif dengan berbasis masalah dapat memecahkan masalah matematika dan kehidupan sehari-hari.

Ansari (2016:100) menyebutkan bahwa pembelajaran kooperatif tipe Think Talk Write merupakan salah satu alternatif pembelajaran yang dapat menumbuh kembangkan kemampuan pemahaman dan komunikasi matematik siswa. Pembelajaran ini pada dasarnya dibangun melalui berpikir, berbicara, dan menulis. Alur pembelajaran think talk write ini dimulai dari keterlibatan siswa dalam berpikir atau berdialog dengan dirinya sendiri setelah proses membaca, selanjutnya berbicara dan membagi ide (sharing) dengan temannya sebelum menulis yang dilakukan dalam kelompok heterogen dengan 3-5 siswa. Dalam kelompok ini siswa diminta membaca, membuat catatan kecil, menjelaskan, mendengar dan membagi ide bersama teman kemudian mengungkapkannya melalui tulisan.

Sedangkan model pembelajaran Think Pair Share (TPS) pertama kali dikembangkan oleh Frank Lyman dan koleganya di Universitas Maryland. Menurut Arends (dalam Ansari, 2016) menyatakan bahwa :

"Think Pair Share (TPS) merupakan suatu cara yang efektif untuk mengganti pola diskusi kelas. Dengan asumsi bahwa semua resitasi atau diskusi membutuhkan pengaturan untuk mengendalikan kelas secara keseluruhan, dan prosedur yang digunakan dalam think pair share dapat memberi siswa lebih banyak waktu untuk berpikir, untuk merespon, dan untuk saling membantu."

Pembelajaran TPS ini diawali dengan thinking yaitu guru mengajukan pertanyaan atau isu yang terkait dengan pelajaran untuk dipikirkan oleh peserta didik. Guru memberikan kesempatan kepada mereka memikirkan jawabannya. Selanjutnya pairing, pada tahap ini guru meminta peserta didik berpasang-pasangan. Memberi kesempatan pasangan-pasangan itu untuk berdiskusi. Kemudian hasil diskusi di tiaptiap pasangan hasilnya dibicarakan dengan seluruh pasangan di dalam kelas, tahap ini dikenal dengan sharing. Dalam kegiatan ini diharapkan tanya jawab yang mendorong pada pengonstruksian pengetahuan secara integratif. Peserta didik dapat menemukan struktur dari pengetahuan yang dipelajarinya (Istarani, 2012:67).

Dengan model pembelajaran Think Talk Write dan Think Pair Share yang lebih menekankan kepada kerja kelompok artinya siswa akan lebih aktif daripada guru dan model tersebut diaplikasikan dalam pembelajaran akan terjadi komunikasi matematis pada siswa sehingga penerapan model pembelajaran Think Talk Write dan Think Pair Share diharapkan dapat memperbaiki kemampuan komunikasi matematis siswa.

Dari hasil penelitian Wati (2016) menyimpulkan bahwa peningkatan prestasi belajar siswa dengan menggunakan model pembelajaran kooperatif tipe TTW dari nilai rata-rata tes pada siklus I mendapatkan 71,47 dengan ketuntasan klasikalnya $43,75 \%$ dan pada siklus II setelah diberi tindakan nilai rata-rata siswa meningkat menjadi 78,88 dengan ketuntasan klasikalnya $81,25 \%$. Kemudian penelitian yang dilakukan oleh Muzayyanah (2009) yang menyimpulkan bahwa pembelajaran dengan menggunakan model pembelajaran kooperatif tipe Think Pair Share mampu meningkatkan kemampuan komunikasi matematika siswa dalam pembelajaran matematika. Pada penelitian diperoleh sebanyak 32 siswa atau 94,12\% dari jumlah siswa mengalami peningkatan skor total kemampuan komunikasi matematika siswa. Dari hasil tes, diperoleh rata-rata tes siswa meningkat dari 61,57 pada siklus I menjadi 75,59 pada siklus II.

Selanjutnya penelitian yang dilakukan oleh Hendarti (2015) mengenai perbandingan kemampuan representasi matematis antara model pembelajaran kooperatif tipe TPS dan TTW. Berdasarkan analisis data, diketahui bahwa rata-rata skor gain kelas TTW sebesar 0,75 dan kelas TPS sebesar 0,63. Hal ini berarti rata-rata skor gain siswa yang mengikuti model

Nuraini, Edy Surya. Perbandingan Kemampuan Komunikasi Matematis Siswa Yang Belajar Dengan Model Pembelajaran Kooperatif Tipe Think Talk Write dan Tipe Think Pair Share di SMP Negeri 3 Percut Sei Tuan. Jurnal Inspiratif, Vol 3, No. 3 Desember 2017. 
pembelajaran kooperatif tipe TTW lebih tinggi dibandingkan dengan siswa yang mengikuti yang mengikuti model pembelajaran kooperatif tipe TPS.

Dari penjabaran di atas dapat disimpulkan bahwa model pembelajaran kooperatif tipe Think Talk Write dan tipe Think Pair Share dapat meningkatkan kemampuan komunikasi matematis siswa.

Permasalahan yang timbul adalah apakah rata-rata skor hasil tes komunikasi matematis siswa yang belajar dengan model pembelajaran kooperatif tipe TTW lebih tinggi daripada model pembelajaran kooperatif tipe TPS?

Tujuan dari penelitian ini adalah untuk mengetahui rata-rata skor hasil tes komunikasi matematis siswa yang belajar dengan model pembelajaran kooperatif tipe TTW lebih tinggi dari siswa yang belajar dengan model pembelajaran kooperatif tipe TPS.

\section{METODE}

Untuk menjawab permasalahan tersebut telah dilakukan penelitian pada siswa SMP Negeri 3 Percut Sei Tuan. Jenis penelitian ini adalah kuasi eksperimen. Desain penelitian yang digunakan adalah Posttest Only Control Group Design. Populasi dalam penelitian ini adalah seluruh siswa kelas VII SMP Negeri 3 Percut Sei Tuan yang terdiri dari 6 kelas. Sampel pada penelitian ini diambil secara cluster sampling dengan kelas VII-2 sebagai kelas eskperimen I yang belajar menggunakan model pembelajaran kooperatif tipe Think Talk Writedan kelas VII-6 sebagai kelas eksperimen II yang belajar menggunakan model pembelajaran kooperatif Think Pair Share. Untuk mengetahui kemampuan komunikasi matematis yang diperoleh dari penerapan pembelajaran tersebut, maka siswa diberikan tes.

Instrumen yang digunakan untuk menentukan kemampuan komunikasi matematis siswa adalah tes. Bentuk tes yang akan digunakan adalah essay test yang disusun berdasarkan indicator kemampuan komunikasi matematis siswa. Dalam penelitian ini, tes yang digunakan adalah tes akhir (posttest) yaitu tes untuk mengetahui kemampuan komunikasi matematis siswa setelah dilakukan pembelajaran dengan materi himpunan.

\section{HASIL DAN PEMBAHASAN}

Berdasarkan hasil analisis data diperoleh deskripsi nilai dari kedua kelas sampel. Hasil perhitungan rata-rata dan standar deviasi tes akhir secara lengkap dilihat pada tabel berikut.

Tabel 1 Data Posttest Kelas Eksperimen I dan Kelas Eksperimen II

\begin{tabular}{|l|c|c|}
\hline Statistik & $\begin{array}{c}\text { Kelas } \\
\text { Eksperimen } \\
\text { I }\end{array}$ & $\begin{array}{c}\text { Kelas } \\
\text { Eksperimen } \\
\text { II }\end{array}$ \\
\hline $\mathrm{N}$ & 36 & 36 \\
\hline Total Skor & 485 & 434 \\
\hline Rata-Rata & 13,4722 & 12,0556 \\
\hline Varians & 2,8278 & 3,0825 \\
\hline $\begin{array}{l}\text { Standari } \\
\text { Deviasi }\end{array}$ & 1,6816 & 1,7557 \\
\hline
\end{tabular}

Berdasarkan tabel di atas dapat dilihat perbedaan kelas eksperimen I dan kelas eksperimen II, dimana rata-rata skor posttest kelas yang menggunakan model pembelajaran kooperatif tipe Think Talk Write lebih tinggi daripada tipe Think Pair Share.

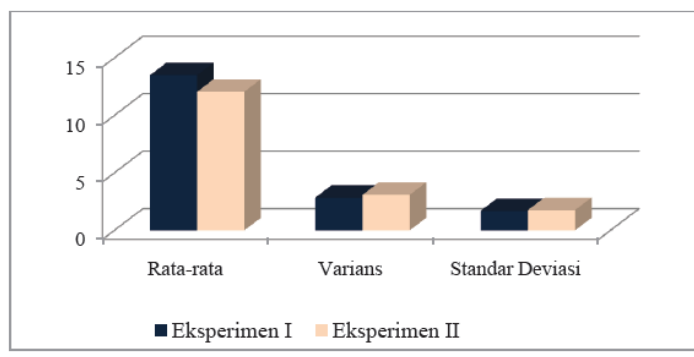

Gambar 1 Diagram Data Posttest Kelas Eksperimen I dan Kelas Eksperimen II

Berdasarkan data pada gambar di atas, diketahui bahwa rata-rata skor posttest kelas eksperimen I lebih tinggi dari ratarata skor posttest kelas eksperimen II, sedangkan untuk varians dan standar deviasi kelas eksperimen II lebih tinggi daripada kelas eksperimen I.

Rata-rata posttest pada kedua kelas berdasar aspek yang terdapat pada

Nuraini, Edy Surya. Perbandingan Kemampuan Komunikasi Matematis Siswa Yang Belajar Dengan Model Pembelajaran Kooperatif Tipe Think Talk Write dan Tipe Think Pair Share di SMP Negeri 3 Percut Sei Tuan. Jurnal Inspiratif, Vol 3, No. 3 Desember 2017. 
kemampuan komunikasi matematis diperlihatkan sebagai berikut.

Tabel 2 Rata-Rata Posttest Berdasar Aspek Komunikasi Matematis

\begin{tabular}{|l|c|c|}
\hline \multicolumn{1}{|c|}{$\begin{array}{c}\text { Aspek } \\
\text { Komunikasi }\end{array}$} & $\begin{array}{c}\text { Kelas } \\
\text { Eksperimen } \\
\text { I }\end{array}$ & $\begin{array}{c}\text { Kelas } \\
\text { Eksperimen } \\
\text { II }\end{array}$ \\
\hline $\begin{array}{l}\text { Membaca } \\
\text { Gambar }\end{array}$ & 3,6389 & 3,7222 \\
\hline $\begin{array}{l}\text { Membuat } \\
\text { Gambar }\end{array}$ & 3,5556 & 3,3889 \\
\hline Menjelaskan & 3,0278 & 2,1667 \\
\hline $\begin{array}{l}\text { Ekspresi } \\
\text { Matematika }\end{array}$ & 3,2500 & 2,7778 \\
\hline
\end{tabular}

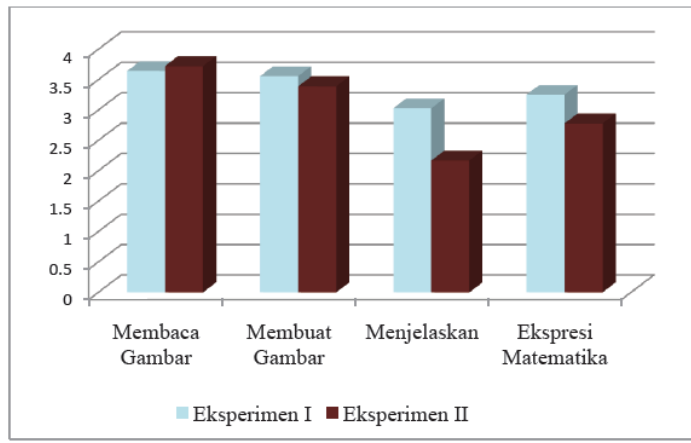

Gambar 2 Rata-Rata Posttest Berdasar Aspek Komunikasi Matematis

Berdasarkan informasi di atas, diketahui bahwa rata-rata skor posttest berdasarkan aspek membaca gambar kelas eksperimen II lebih tinggi daripada kelas eksperimen I sedangkan rata-rata skor untuk aspek membuat gambar, menjelaskan dan ekspresi matematika kelas eksperimen I lebih tinggi daripada kelas eksperimen II. Data ini selanjutnya akan digunakan sebagai landasan untuk melakukan uji statistik.

\section{A. Uji Normalitas Data}

Uji normalitas dilakukan untuk mengetahui apakah sampel data berasal dari populasi berdistribusi normal atau tidak. Secara umum, sampel berdistribusi normal jika dipenuhi $\mathrm{L}_{0} \leq \mathrm{L}_{\text {tabel }}$ pada taraf signifikan $\alpha=0,05$.
Tabel 3. Data Hasil Uji Normalitas

\begin{tabular}{|c|c|c|c|c|c|}
\hline \multicolumn{2}{|c|}{$\begin{array}{c}\text { Eksperime } \\
\text { n I } \\
\text { (TTW) } \\
\end{array}$} & \multirow{2}{*}{$\begin{array}{c}\text { Keteran } \\
\text { gan }\end{array}$} & \multicolumn{2}{|c|}{\begin{tabular}{|c} 
Eksperime \\
n II \\
(TPS) \\
\end{tabular}} & \multirow{2}{*}{$\begin{array}{c}\text { Keteran } \\
\text { gan }\end{array}$} \\
\hline $\mathbf{L}_{\text {hitun }}$ & $\mathbf{L}_{\text {tabel }}$ & & $\mathbf{L}_{\text {hitun }}$ & $\mathbf{L}_{\text {tabel }}$ & \\
\hline .100 & 0,14 & \multirow[t]{2}{*}{ Normal } & 0.101 & 0,147 & \multirow[t]{2}{*}{ al } \\
\hline 5 & 77 & & 2 & & \\
\hline
\end{tabular}

Dari Tabel 3 dapat disimpulkan bahwa data pada kedua kelompok sampel berdistribusi normal.

\section{B. Uji Homogenitas Data}

Pengujian homogenitas data dilakukan dengan menggunakan uji $\mathrm{F}$ pada data posttest dengan rumus sebagai berikut.

$$
F_{\text {hitung }}=\frac{\text { var iansterbesar }}{\text { variansterkecil }}
$$

Tabel 4. Data Hasil Uji Homogenitas

\begin{tabular}{|c|c|c|c|c|}
\hline \multicolumn{2}{|c|}{ Varians } & \multirow{2}{*}{$\mathbf{F}_{\text {hitung }}$} & \multirow{2}{*}{$\mathbf{F}_{\text {tabel }}$} & \multirow{2}{*}{$\begin{array}{c}\text { Keterang } \\
\text { an }\end{array}$} \\
\hline Eks 1 & Eks 2 & & & \\
\hline 2,8278 & 3,0825 & $\begin{array}{l}1.090 \\
1\end{array}$ & $\begin{array}{l}1,757 \\
1\end{array}$ & Homogen \\
\hline
\end{tabular}

Dari Tabel 4. dapat disimpulkan bahwa kedua kelas homogen.

Berdasarkan tabel 3.3. dan 3.4 dapat disimpulkan bahwa telah memnuhi syarat untuk dilakukan uji beda rata-rata dengan uji-t.

\section{Uji Hipotesis Data}

Hipotesis yang diuji untuk posttest adalah :

$$
\begin{array}{ll}
H_{o}: & \mu_{1} \leq \mu_{2} \\
H_{a}: & \mu_{1}>\mu_{2}
\end{array}
$$

Pengujian hipotesis ini dilakukan dengan uji-t satu arah, dengan kriteria yaitu terima $\mathrm{H}_{0}$ jika $\mathrm{t}_{\text {hitung }}<\mathrm{t}_{\text {tabel }}$. Dimana didapat dari daftar distribusi $\mathrm{t}$ dengan $\mathrm{dk}=$ $\left(n_{1}+n_{2}-2\right)$ pada taraf signifikan $\alpha=0,05$, untuk harga t lainnya $\mathrm{H}_{0}$ ditolak.

Tabel 5 Data Hasil Uji Hipotesis

\begin{tabular}{|c|c|c|c|}
\hline \multicolumn{2}{|c|}{ Rata-rata } & \multirow{2}{*}{$\mathrm{t}_{\text {hitung }}$} & \multirow{2}{*}{$\mathrm{t}_{\text {tabel }}$} \\
\cline { 1 - 2 } Eks 1 & Eks 2 & & \\
\hline 13,4722 & 12,0556 & 3,4961 & 1,6683 \\
\hline
\end{tabular}

Dari data posttest di atas diperoleh bahwa $t_{\text {hitung }}>t_{\text {tabel }}$ pada taraf $\alpha=0,05$ dan $\mathrm{dk}=36+36-2=70$. Yang berarti $\mathrm{H}_{0}$

Nuraini, Edy Surya. Perbandingan Kemampuan Komunikasi Matematis Siswa Yang Belajar Dengan Model Pembelajaran Kooperatif Tipe Think Talk Write dan Tipe Think Pair Share di SMP Negeri 3 Percut Sei Tuan. Jurnal Inspiratif, Vol 3, No. 3 Desember 2017. 
ditolak sehingga dapat disimpulkan bahwa kemampuan komunikasi matematis siswa yang belajar dengan model pembelajaran kooperatif tipe Think Talk Write lebih tinggi dari kemampuan komunikasi matematis yang belajar dengan model pembelajaran kooperatif tipe Think Pair Share di kelas VII SMP Negeri 3 Percut Sei Tuan.

Hal ini sesuai dengan penelitian Ikashaum (2014), yang menunjukkan bahwa kemampuan representasi siswa dengan model pembelajaran TTW lebih tinggi daripada kemampuan representasi siswa dengan model pembelajaran TPS.

Pembelajaran kooperatif menuntut siswa untuk bekerjasama dengan kelompoknya untuk menyelesaikan suatu permasalahan. Dengan begitu siswa akan bertanggungjawab atas belajarnya sendiri dan berusaha menemukan informasi untuk menjawab pertanyaan-pertanyaan yang diberikan pada mereka. Hal ini didukung oleh teori Piaget yang memandang penting dibentuknya kelompok belajar sehingga setiap anak memiliki rasa tanggungjawab dan merasa adanya saling ketergantungan secara positif karena setiap anggota memiliki peran serta dalam mencapai keberhasilan kelompoknya. Selain teori Piaget, pembelajaran kooperatif juga didukung oleh teori Vygotsky dikarenakan dalam model pembelajaran ini terjadi interaksi sosial, yaitu interaksi antar peserta didik maupun antara peserta didik dengan guru (Trianto, 2011:30).

Dalam proses penelitian, pembelajaran dengan model kooperatif tipe TTW dilaksanakan sesuai dengan langkahlangkah proses pembelajaran kooperatif tipe TTW. Kelompok siswa yang terdiri dari 5 orang berpikir, kemudian membahas masalah yang terdapat pada LAS dalam kelompok mereka kemudian menyimpulkan jawaban mereka menjadi sebuah tulisan. Dalam diskusi kelompok pada fase talk masing-masing anggota dalam satu kelompok saling membantu satu sama lain dalam penguasaan materi dan memastikan seluruh anggota kelompok menguasai materi yang dipelajari guna tercapai keberhasilan kelompok. Setiap anggota memiliki rasa tanggungjawab terhadap dirinya sendiri untuk berkomunikasi dengan baik. Berdasarkan pengamatan di kelas pada proses pembelajaran dengan menggunakan model pembelajaran kooperatif tipe TTW, tiap anggota kelompok mampu memberikan kontribusinya dan mengoptimalkan interaksi terhadap 4 anggota lainnya. Pada saat diskusi kelompok siswa aktif bertanya sehingga memberikan pengaruh positif terhadap pemahaman setiap siswa. Pada saat berlangsungnya diskusi kelompok, guru dapat dengan mudah mengelola kelas karena siswa tidak berjalan kesana kemari. Hal ini dapat mendukung model pembelajaran kooperatif tipe TTW agar diterapkan oleh guru pada proses pembelajaran.

Pada proses pembelajaran dengan model kooperatif tipe TPS, pembelajaran dilaksanakan sesuai langkah-langkah pembelajaran kooperatif tipe TPS, yaitu siswa berdiskusi secara berpasangan. Setelah setiap siswa memiliki pasangan, mereka berada pada fase share, yaitu berkomunikasi, berdiskusi dan bertukar pendapat terhadap ide dan materi yang sedang dibahas pada proses pembelajaran. Dari hasil pengamatan di kelas pada proses pembelajaran dengan model pembelajaran kooperatif tipe TPS, terdapat kesulitan dalam memberi arahan dan mengelola kelas karena banyaknya kelompok yang terbentuk sehingga menimbulkan kegaduhan di dalam kelas.

Meskipun demikian, baik TTW maupun TPS ternyata sama-sama dapat meningkatkan kemampuan komunikasi matematis siswa di kedua kelas tersebut. Hal itu sejalan dengan penelitian yang dilakukan oleh Husnah dan Surya (2017), yang menyatakan bahwa, penggunaan dari model pembelajaran Think Talk Write ini efektif untuk meningkatkan kemampuan komunikasi matematis siswa kelas VIII di MTs Al Jami'yatul Washliyah Tembung. Dan juga diperkuat dengan hasil uji gain penggunaan dari model Think Talk Write efektif pada kemampuan komunikasi matematis siswa, dapat dilihat dari persentase efektivitas prestasi belajar

Nuraini, Edy Surya. Perbandingan Kemampuan Komunikasi Matematis Siswa Yang Belajar Dengan Model Pembelajaran Kooperatif Tipe Think Talk Write dan Tipe Think Pair Share di SMP Negeri 3 Percut Sei Tuan. Jurnal Inspiratif, Vol 3, No. 3 Desember 2017. 
matematika pada siswa kelas eksperimen yang lebih besar dari persentase prestasi belajar siswa di kelas kontrol. Pada penelitian Sumirat (2014) juga menunjukkan bahwa penerapan strategi pembelajaran kooperatif tipe TTW lebih efektif dalam meningkatkan kemampuan komunikasi matematis siswa jika dibandingkan dengan pembelajaran konvensional tipe ekspositori dan juga didukung oleh hasil postes yang menunjukkan bahwa kemampuan komunikasi matematis siswa tergolong tinggi.

Dalam penelitian Nurjaman (2015) menyatakan bahwa ada perbedaan rata-rata kemampuan komunikasi matematis antara kelompok eksperimen yang diajar model pembelajaran kooperatif tipe TPS dan kelompok kontrol yang diajar secara konvensional. Dalam persentase rataan skor setelah diberi perlakuan, menunjukkan bahwa persentase kemampuan komunikasi matematis kelompok eksperimen lebih tinggi dibandingkan persentase kelompok kontrol. Pada penelitian yang dilakukan Nasution dan Surya (2017) juga menunjukkan bahwa penerapan model pembelajaran kooperatif tipe Think Pair Share dapat meningkatkan hasil belajar siswa. Hal ini dapat dilihat dari persentase kenaikan siklus I hingga siklus III yaitu dari $56,7 \%$ hingga $86,7 \%$ yang berarti tuntas dengan kriteria tinggi.

Dari rata-rata hasil kemampuan komunikasi matematis dan pengujian beda rata-rata terbukti bahwa kemampuan komunikasi matematis siswa yang belajar dengan menggunakan model pembelajaran kooperatif tipe Think Talk Write lebih tinggi daripada kemampuan komunikasi matematis siswa yang belajar dengan menggunakan model pembelajaran kooperatif tipe Think Pair Share.

Diharapkan ke depannya guru dapat terus merancang/merencanakan, memantau, mengevaluasi, dan merefleksi serta terus memperbaiki kekurangan, kesulitan dan dapat mengatasi permasalahan yang muncul sehingga siswa memahami konsep matematika secara luwes, akurat, efesiarn, dan tepat serta memiliki sikap menghargai kegunaan matematika dalam kehidupan yaitu memiliki rasa ingin tahu atau kritis, perhatian dan minat dalam mempelajari matematika, serta sikap ulet dan percaya sendiri dalam pemecahan masalah matematika (Surya, 2012)

\section{KESIMPULAN}

Berdasarkan hasil penelitian maka dapat disimpulkan bahwa kemampuan komunikasi matematis siswa yang belajar dengan model pembelajaran kooperatif tipe Think Talk Write (TTW) lebih tinggi daripada kemampuan komunikasi matematis siswa yang belajar dengan model pembelajaran kooperatif tipe Think Pair Share (TPS) di SMP Negeri 3 Percut Sei Tuan. Aspek kemampuan komunikasi matematis siswa pada pembelajaran kooperatif tipe TTW yang mempunyai ratarata skor lebih tinggi adalah aspek kemampuan membuat gambar, menjelaskan dan ekspresi matematika, sedangkan aspek kemampuan komunikasi matematis siswa pada pembelajaran kooperatif tipe TPS yang mempunyai rata-rata skor lebih tinggi adalah aspek kemampuan membaca gambar.

\section{DAFTAR PUSTAKA}

Ansari, B.I., (2016), Komunikasi Matematik Strategi Berfikir dan Manajemen Belajar : Konsep dan Aplikasi, Penerbit Pena, Banda Aceh.

Fachrurazi, (2011), Penerapan Pembelajaran Berbasis Masalah Untuk Meningkatkan Kemampuan Berpikir Kritis dan Komunikasi Matematis Siswa Sekolah Dasar,Forum Penelitian Edisi Khusus No. 1, hal 76-89.

Hendarti, T., Tina, Y., \& Rini, A., (2015), Perbandingan Kemampuan Representasi Matematis Antara Model Pembelajaran Kooperatif Tipe TPS dan TTW, https://drive.google.com/file/d/OB-

Nuraini, Edy Surya. Perbandingan Kemampuan Komunikasi Matematis Siswa Yang Belajar Dengan Model Pembelajaran Kooperatif Tipe Think Talk Write dan Tipe Think Pair Share di SMP Negeri 3 Percut Sei Tuan. Jurnal Inspiratif, Vol 3, No. 3 Desember 2017. 
k3cSUkM3IyclA

OYkZZTOO5eEU/view.

Husnah, N.U., \& Surya, E., (2017), The Effectiveness of Think Talk Write Learning Model in Improving Students' Mathematical Communication Skills at MTs Al Jami'yatul Washliyah Tembung, International Journal of Sciences:Basic and Applied Research (IJSBAR) Vol 34 No 2.

Ikashaum, F., Tina, Y. \& Sugeng, S., (2014), Perbandingan Kemampuan Representasi Matematis Siswa Antara Model Pembelajaran TTW Dan TPS, Jurnal Pendidikan Matematika Unila, Vol. 2 No. 3.

Isjoni, (2011), Cooperative Learning Mengembangkan Kemampuan Belajar Berkelompok, Alfabeta, Bandung.

Istarani, (2012), 58 Model Pembelajaran Inovatif, Media Persada, Medan.

Lomibao, L.S., Charita, A.L. \& Rhoda, A. M., (2016), The Influence of Mathematical Communication on Students Mathematics Performance and Anxiety, American Journal of Educational research Vol. 4 No. 5.

Mardiyah, (2014), Studi Kasus Kesulitan Belajar Matematika SIswa Ditinjau Dari Segi Kemampuan Komunikasi Matematika, Prosiding Seminar Nasional Pendidikan Matematika Program Pasca Sarjana STKIP Siliwangi Bandung Vol. 1, ISSN : 2355-0473.

Muzayyanah, A., (2009), Peningkatan Kemampuan Komunikasi Matematika Siswa Dalam Pembelajaran Matematika Melalui Model Pembelajaran Kooperatif Tipe Think Pair Share (TPS) di SMA Negeri 1 Godean, Prosiding Seminar Nasional Pembelajaran Matematika
Sekolah, Yogyakarta, UNY, 6 Desember 2009, ISBN : 978-97916353-4-9.

Nartani, C. I., Rosidah, A. H. \& Yohana, S., (2015), Communication in Mathematics Contextual, International Journal of Innovation and Research in Educational Sciences Vol. 2 Issue 4, ISSN : 23495219.

Nasution, F.S. \& Surya, E., (2017), Efforts to Increase Student Learning Results with Cooperative Learning Type Learning Model Think Pair Share on the Cube and Beams Materials in Class VIII SMP Kartika I-1 Medan, International Journal of Sciences:Basic and Applied Research (IJSBAR) Vol 33 No 3.

Nurjaman, A., (2015), Meningkatkan Kemampuan Komunikasi Matematik Siswa SMP Melalui Model Pembelajaran Kooperatif Tipe Think Pair Share (TPS), Jurnal Ilmiah STKIP Siliwangi Bandung Vol 9 No 1, ISSN 1978-5089.

Rahmalia, Y., Armiati \& Jazwinarti, (2012), Meningkatkan Kemampuan Komunikasi Matematis Siswa Melalui Penerapan Model Pembelajaran Kooperatif Teknik Nimbered Head Together (NHT), Jurnal Pendidikan Matematika Vol. 1 No. 1.

Ramellan, P., Edwin, M. \& Armiati, (2012). Kemampuan Komunikasi Matematis dan Pembelajaran Interaktif, Jurnal Pendidikan Matematika, Vol. 1 No. 1.

Suhaedi, D., (2012), Peningkatan Kemampuan Komunikasi Matematis Siswa SMP Melalui Pendekatan Pendidikan Matematika Realistik, Makalah dipresentasikan dalam Seminar Nasional Matematika dan Pendidikan Matematika, Yogyakarta,

Nuraini, Edy Surya. Perbandingan Kemampuan Komunikasi Matematis Siswa Yang Belajar Dengan Model Pembelajaran Kooperatif Tipe Think Talk Write dan Tipe Think Pair Share di SMP Negeri 3 Percut Sei Tuan. Jurnal Inspiratif, Vol 3, No. 3 Desember 2017. 
UNY 10 November 2012, ISBN : 978-979-16353-8-7.

Sukendar, E., (2014), Upaya Meningkatkan Kemampuan Komunikasi Matematik Siswa Madrasah Tsanawiyah Menggunakan Model Pembelajaran Kooperatif, Prosiding Seminar Nasional Pendidikan Matematika Program Pasca Sarjana STKIP Siliwangi Bandung Vol. 1, ISSN : 2355-0473.

Sumirat, L. A., (2014), Efektifitas Strategi Pembelajaran Kooperatif Tipe Think Talk Write (TTW) Terhadap Kemampuan Komunikasi Dan Disposisi Matematis Siswa, Jurnal Pendidikan dan Keguruan, Vol. 1 No. 2.

Surya, E. 2009. "Pembelajaran Kooperatif dengan Pendekatan Berbasis Masalah dalam Pemecahan Masalah Matematika". Jurnal Pendidikan Matematika dan Sains, IV (1), 14-17.

Surya E. 2013. Analisis Pemetaan dan Pengembangan Model Pembelajaran Matematika SMA di Kabupaten Tapteng dan Kota Sibolga Sumatera Utara. Jurnal Pendidikan Matematika PARADIKMA, Vol 6 Nomor 1, hal 75-88.

Surya, E. (2012). "Upaya Pembelajaran Matematika Berbasis Masalah dengan Strategi Konflik Kognitif". Jurnal Tematik. PPS Dikdas Unimed . 7, (1), 1-14,

Syaifuddin, M.W., (2013), Eksperimentasi Model Pembelajaran Kooperatif Tipe Teams Assisted Individualization (TAI) Pada Pokok Bahasan Relasi Dan Fungsi Ditinjau Dari Kemampuan Awal Siswa, Magistra No. 83 Th XXV Maret 2013, ISSN : 0215-9511.
Tinungki, G. M., (2015), The Role of Cooperative Learning Type Team Assisted Individualization to Improve the Students' Mathematics Communication Ability in the Subject of Probability Theory, Journal of Education and Practice Vol. 6 No. 32, ISSN 2222-288X.

Trianto, (2011), Mendesain Model Pembelajaran Inovatif-Progresif : Konsep, Landasan, dan Implementasinya Pada Kurikulum Tingkat Satuan Pendidikan (KTSP), Kencana Prenada Media Group, Jakarta.

Umar, W., (2012), Membangun Kemampuan Komunikasi Matematis Dalam Pembelajaran Matematika, Jurnal Ilmiah Program Studi Matematika STKIP Siliwangi Bandung Vol. 1 No. 1 Februari 2012.

Wati, F. A. \& Supriyono, (2016), Peningkatan Kemampuan Komunikasi Matematis Menggunakan Model Pembelajaran Kooperatif Tipe TTW Pada Siswa Kelas VII A. https://drive.google.com/file/d/OB$k 3 c S U k$ M3IycFBNUmIIaHdhOUE/view.

Nuraini, Edy Surya. Perbandingan Kemampuan Komunikasi Matematis Siswa Yang Belajar Dengan Model Pembelajaran Kooperatif Tipe Think Talk Write dan Tipe Think Pair Share di SMP Negeri 3 Percut Sei Tuan. Jurnal Inspiratif, Vol 3, No. 3 Desember 2017. 